\title{
An Overhead Costs Assessment for Construction Projects at Gaza Strip
}

\author{
Nabil I. El-Sawalhi ${ }^{1}$, Ahmed El-Riyati ${ }^{2}$ \\ ${ }^{1}$ Civil Engineering Department, The Islamic University, Gaza, Palestinian Territories \\ ${ }^{2}$ United Nations Development Program, Gaza, Palestinian Territories
}

Email address:

nsawalhi@iugaza.edu.ps (N. I. El-Sawalhi), ariyati@undp.org (A. El-Riyati)

\section{To cite this article:}

Nabil I. El-Sawalhi, Ahmed El-Riyati. An Overhead Costs Assessment for Construction Projects at Gaza Strip. American Journal of Civil Engineering. Vol. 3, No. 4, 2015, pp. 95-101. doi: 10.11648/j.ajce.20150304.11

\begin{abstract}
An overhead cost of projects has significant role and influence on the performance of the construction companies. In addition, maintaining a good performance and quality of work away from possible loss. The purpose of the research is to examine the overhead costs management practice in the construction industry in the Gaza Strip. The awareness of construction companies and techniques followed by the contractors in estimating the overhead costs, affecting factors and mitigation measures was examined. A structured questionnaire supported by personal interviews was used to collect information. Sixtythree contracting companies working in the construction industry in the Gaza Strip were surveyed. The analysis shows a good awareness of the concept of overheads costs and its components. Gaza Strip Contractors follow precise practices to estimate the overheads costs. Contractors are taking several precautionary measures to minimize any risks associated with overheads costs. Factors affecting the estimation of overhead costs are including the management capacity of the company and its policy, led by the company's experience and ability to implement the project within the time frame. There are other factors related to the working environment of the project, especially the closure of commercial crossings of the Gaza.
\end{abstract}

Keywords: Project Overhead, Home Office Overhead, Construction

\section{Background}

The percentage of overhead in cost estimation is considered principal parameter in estimating the financial value of bid offer [1]. Many contractors take the risk and not consider the actual cost of overhead, especially the home office overhead in order to win the tender. Hence, neglecting overhead cost has forced some contractors out of business [2] In construction industry, any increased overhead costs will include both site overhead and home-office overhead [3]. In Gaza Strip, the disturbance in commercial market resulted from closing the trade terminal for long periods, prevention of selected raw material and delaying materials entrance has increased the risk of contractors. These actions have created many problems and delay which is out of control of the two parties of contracting. Hence, the overhead of construction companies and the clients has increased became tangible. In order to verify overhead cost in the tenders, few contracts have separate items for overhead and profit. Most contracts tell contractor to spread or allocate their overhead and profit costs across all pay items in the schedule of values [4].
Under these circumstances, it is not surprising that the number of disputes and claims within the construction industry continues to increase because of increasing the overhead. Thus, in many times suspension of projects and delays in execution are considered from the main causes of increasing the overhead costs. In many countries, cases of overhead disputes between the two parties are carried to the arbitration or court. Therefore, it is very essential to pay attention to have solid evidences and documentation instead of foggy presentation [5].

The construction industry in Gaza Strip became indeed to judicious management can face all obstacles and be able to minimize the disputes between the parties. Minimization of these disputes need tight and fair contract clauses in addition to presenting guidance for the risks should be in consideration within any contractual process regarding the overhead cost. On the other hand, the contractor should be aware about the important of accurate estimation of the overhead in their projects to avoid any damages which may occur. The main aim of this research is to assess the overhead cost in constructions projects and explore the factors effecting on projects overheads costs. 


\section{Construction Overhead}

General expenses of the construction project are defined as the additional, indirect costs that are necessary for the facilitation of the construction project. However, this definition inadvertently causes confusion by linking indirect costs and general expenses [4, 6, 7]. Overhead cost can be defined as a cost that cannot be identified with or charged to a construction project or to a unit of construction production [8]. Therefore, overhead costs generally are divided into two categories: general overhead costs and job overhead costs [9]

General overhead costs are those costs that cannot be identified readily with a specific project. General overhead costs are items that represent the cost of doing business and often are considered as fixed expenses that must be paid by the contractor [2].

\subsection{Field Overhead}

Field overheads are defined as the general cost or direct cost of the project for providing general plant and site-based services like insurance, site accommodation, etc [10]. It mainly consists of the costs expended to manage and administer a specific project (e.g., the cost of providing a job site office) [11]. In other words, it is used to quantify overhead costs that are incurred in the field [12]. Table 1 shows items that might qualify as field overhead costs as specified by [12].

Table 1. Field overhead items.

\begin{tabular}{ll}
\hline Possible Field Overhead Items & \\
\hline Office Trash Removal & Airfare - Home Office Personnel \\
Office/Field Water Ice & Builders Risk Insurance \\
Portable Toilets & Cell Phones \\
Postage \& Shipping & Engineers' Office Rent \\
Safety Supplies & Field Office Expenses \\
Telephones & Insurances Required by contract \\
Utilities & Lodging - Home Office Personnel \\
Yard Rent & Miscellaneous Expenses \\
Yard Tools \& Supplies & Office Security \\
Office Trailer Rental & \\
\hline
\end{tabular}

Field overhead costs include items that can be identified with a particular job, but are not materials, labor, or production equipment. Job overhead includes expenses that cannot be charged directly to a particular branch of work, but are required to construct the project [2]. Job overhead (field overhead) is similar to general overhead but it must be distributed over the associated project, since it cannot be allocated to specific work packages [13].

An increase in site overhead expenses is usually easier to quantify. It requires the contractor to disclose its buildup of site preliminaries, showing detailed costs for all items considered as general site items (site infrastructure, cranes, and other general site equipment) [3]. According to reference [14], Indirect costs allocable to contracts include the costs of indirect labor, contract supervision, tools and equipment, supplies, quality control and inspection, insurance, repairs and maintenance, depreciation and amortization, and, in some circumstances, support costs, such as central preparation and processing of payrolls.

\subsection{Home Office Overhead (HOOH)}

General overhead expenses include the general business expenses that are incurred by the home office in support of the company construction program [15]. In other words, home office overhead represents the costs of the activities of the Contractor's home, or corporate, office necessary to run the business and to support the projects in the field [16].

General overhead costs (main-office or home-office expenses) are intended to include all those expenses incurred by the home office that cannot be tied directly to a given project such as home-office building rental, clerical, or utilities [13]. Therefore, these costs are distributed over all company projects by some basis [6]. It should be made clear that general and administrative costs are also referred to an overhead and in fact are part of the contractor's total overhead [14].

$\mathrm{HOOH}$ is generally described as company costs incurred by the contractor for the benefit of all projects in progress. This is the actual cost, which is an essential part of the cost of doing business. These costs cannot be directly allocated to a project. Contractors are reasonably free to account for such costs in whatever manner they choose. They must, however, use the same system at all times and on all contracts [4, $14,16]$.

Home office overhead costs include but are not limited to [11]: Rent; Utilities; Furnishings; Office equipment; Executive staff; Support and clerical staff not assigned to the field; Estimators and schedulers not assigned to field staff; Mortgage costs; Real estate taxes; Automobile maintenance and travel costs for home office personnel; Non-projectrelated bond or insurance expenses; Depreciation of equipment and other assets; Advertising; Marketing; Office supplies (paper, staples, etc.); Interest; Legal services; Accounting and data processing; and Professional fees/registrations.

\subsection{Technique of Overhead Estimation in Project}

Reference [17] mentions that estimating the project indirect cost is a time-consuming and inexact task, and hence contractors often apply a percentage of direct costs as an estimate of indirect cost. The method of applying a fixed percentage to the total value for project overheads allowance is particularly common in case of small-scaled, repetitive works. However, this may result in under-estimation, as many preliminary items bear no linear relationship to the value of works [10]. Reference [9] criticized that some contractors will multiply the direct cost by a certain percentage to get the overhead cost. However, such a quick method may not be sufficiently accurate for most estimates.

More sophisticated estimation models using ANN [18, 19], fuzzy modeling [20], and simulation models [21] are proposed by many authors as being effective tools for cost estimation, but few are practiced in reality [22]. Whereas the estimation method for project overheads is more primitive 
due to lack of serious concerns [10].

In summary most of the estimators still relied on their experience to work out the estimates without much use of artificial intelligence. On the other hand, reference [10] mentioned that despite of advancement in IT in recent years, IT application in construction estimation by the contractors is still limited.

\subsection{Factor Affecting Estimation of Overhead}

The estimation of overhead percentage as presented by [23] was influenced by historical data of the projects; a forecast of future activity, the ratio between main contractors' and subcontract work, competitive conditions, the size, nature and duration of the project and an evaluation of risk. Furthermore, reference [11] added that the profit potential of individual projects is driven by many factors, including the contract terms and the level of competition.

The project's duration, total contract value, projects type, special site preparation needs and project's location are identified as the top five factors that affect the value of the percentage of site overhead costs for building construction projects in Egypt[24].

\section{Research Methodology}

The researcher has reviewed the relevant literature of overhead costs in construction projects. A structured questionnaire addressed to owners and contractors was prepared. It aims to get their feedback about factors that affecting the overhead costs in construction projects and how to minimize these costs. It also explores how much they are aware of the parameters of overhead, and the risk related to the estimation of overhead in their projects. The questionnaire was distributed among the contractors to obtain their perspectives regarding the mentioned aspects of the overhead in construction projects in Gaza Strip.

Statistical analysis and tests has been conducted by using Statistical Program for Social Science (SPSS). In order to get an appropriate method of analysis, the level of measurement must be understood and simple. Ordinal scales were used. Based on Likart scale researcher has the following: $1=$ Not Important, 2= Low Importance, 3= Medium Importance, 4= Important and 5= Very Important.

To determine the Relative Importance Index (RII) of the factors, these scores were transformed to importance relative indices based on the formula:

$$
\begin{gathered}
\text { Relative Importance Index (RII) }= \\
\frac{\sum \mathrm{w}}{\mathrm{AN}}=\frac{5 \mathrm{n}_{5}+4 \mathrm{n}_{4}+3 \mathrm{n}_{3}+2 \mathrm{n}_{2}+1 \mathrm{n}_{1}}{5 \mathrm{~N}}
\end{gathered}
$$

Where $\mathrm{W}$ is the weight given to each factor by the respondent, ranging from 1 to $5,(\mathrm{n} 1=$ number of respondents for Very Important, n2 = number of respondents for Important, $\mathrm{n} 3=$ number of respondents for Medium Importance, $\mathrm{n} 4=$ number of respondents for Low Importance, $\mathrm{n} 5=$ number of respondents for No Importance). A is the highest weight (i.e. 5 in the study) and $\mathrm{N}$ is the total number of respondents. The RII equals ranges from 0 to 1 . A one respondents t-test was used to test if the opinion of the respondents in the content of the sentences positive if RII $\geq 0.6$ and the p-value less than 0.05 , or neutral If the p-value greater than 0.05 , or negative RII $\leq$ 0.6 and the p-value less than 0.05 .

\section{Results and Analysis}

$34.34 \%$ from the respondents companies are working in buildings, while $25.30 \%$ is roads, $22.89 \%$ is water and sewage, $13.25 \%$ is electro mechanical works, and $4.22 \%$ are working in other types. Furthermore, $72.1 \%$ of respondents are company owner, $26.2 \%$ is projects manager, and $1.6 \%$ from the respondents is office engineer. This result shows that the overhead management has pushed the seniors to participate and bring out their opinion in sensitive part of construction management. Hence, the participation of seniors will add more realistic and reliability to the coming results.

9.8\% from the respondents have implemented projects with total value of one million dollars or less within the past five years, while $44.3 \%$ from 1.1 to 3.0 million, $29.5 \%$ from 3.1 to 7.0 million, $13.1 \%$ from 7.1 to 15.0 million, and $3.3 \%$ more than 15.0 million. The above result shows that the majority of companies are located between one and seven million US Dollar. This results may refer to the small size of project that undertaken in Gaza Strip and the high competition between companies in Gaza.

The majority is located between three to seven projects, which are normal to the capacities of Gaza contracting companies that have low financial and administrative capabilities.

$21.3 \%$ from the companies are working since four to nine years, while $44.3 \%$ are working since ten to fifteen years, and $34.4 \%$ from the companies are working for more than fifteen years. The results above show that the majority of companies were established after the establishment of Palestinian Authority in 1994, whereas intensive construction projects has implemented in the Palestinian territories.

\subsection{Knowledge and Sources of Information About the Overhead Costs}

The question was raised to get the feedback about how much are the contractors aware towards overheads concept and how much they have knowledge about the components of overheads. Results show that $16.39 \%$ replied with partially reasonable definition, and $31.15 \%$ replied by reasonable accurate definition. The results are close to the results of [1] in Saudi Arabia, whereas, 23\% of the respondents has defiend $\mathrm{OH}$ with reasonable accurate definition. Some of the reasonable definitions as specified by the respondents are " Everything related to the project costs other than the cost of raw materials, labor and workmanship";" All the expenses of the project staff and other needs during the period of the project which located outside the scope of construction, in addition to the requirements to run the company main office"; "The expenses necessary for the implementation and 
management of the project and often not directly mentioned as items in the bill of quantities, the costs of the supervision required for the project implementation, in addition to the administrative and technical cost for the company home office"; "The costs spent on project management and management of the company, and these costs is loaded on the projects items". The results show that most of contractors don't have specific definition or proper understanding of the $\mathrm{OH}$ term.

Table 2 show the responsible for estimating the overheads costs during the pricing of tenders. $65.6 \%$ from the respondents who usually estimate the overheads costs during the pricing of tenders is "company owner", while $27.9 \%$ is "specialized employee in pricing", and $6.6 \%$ shows that "senior employee" is usually estimate overheads costs during the pricing of tenders.

Table 2. Estimator for the overheads costs during the pricing of tenders.

\begin{tabular}{lll}
\hline Percent (\%) & Frequency & Estimator \\
\hline 65.6 & 40 & Company owner \\
27.9 & 17 & Specialized employee in pricing \\
6.6 & 4 & Senior employee \\
100 & 61 & Total \\
\hline
\end{tabular}

These results indicate that overheads estimation is very important and critical to win tender. Seniors in a company is requested to evaluate the project nature and the work environment. Hence, they can judge the overheads accurately. It can be summarized that overheads cost is not like any work items which can be estimated depending on clear cost, but it depends on many factors that should be known well by the experience seniors in the company.

When asking about the sources used for estimating the overheads costs; Table 3 show that $6.6 \%$ has used the company records as a sources to estimate the overheads costs. While $31.1 \%$ has to use stakeholders such as insurance companies, banks, and services providers etc. 59.0\% has used of both sources (company records \& stakeholders) and 3.3\% has used another sources.

Table 3. The sources used for estimating the overheads costs.

\begin{tabular}{lll}
\hline Percent (\%) & Frequency & Sources \\
\hline 6.6 & 4 & Records of the company \\
31.1 & 19 & Use stakeholders \\
59.0 & 36 & Both resources \\
3.3 & 2 & Another resources \\
100 & 61 & Total \\
\hline
\end{tabular}

The above results show that the majority of companies does not depend heavily on records only but also depends on the stakeholder information. Similar results were illustrated by [10], whereas $19 \%$ depends on company database and records, $31 \%$ depends on suppliers and stakeholders, and $50 \%$ referred to both.

Table 4 shows that $23.0 \%$ of companies depend on one year historical data to estimate prices, while $19.7 \%$ says they use two years. $18.0 \%$ says that they use three years records, $8.2 \%$ says they used four years or more, and $31.1 \%$ says that they do not depend on the historical data to estimate the prices. Almost the same results founded by [6] where $30 \%$ of respondents do not apply the historical data at all.

Table 4. Using the historical data records.

\begin{tabular}{lll}
\hline Percent (\%) & Frequency & Number of years \\
\hline 23.0 & 14 & One year \\
19.7 & 12 & Two years \\
18.0 & 11 & Three years \\
8.2 & 5 & Four years or more \\
31.1 & 19 & Not applicable \\
100 & 61 & Total \\
\hline
\end{tabular}

Instability of political situation enforced the contractor to minimize the dependency on historical data. Whereas, about one third of the respondents do not depend the historical data and about one fourth of respondents just depend on one year historical data to estimate prices.

\subsection{Methods Used to Determine the Field Overheads Costs}

Table 5 shows that $70.5 \%$ says that the method followed by their company to determine the field overheads costs mainly depends on the detailed calculation which based on the contractual condition. While, $8.2 \%$ says that the method depends on adding a percentage to the total tender cost. $3.3 \%$ says that the method depends on a lump sum added to the value of the tender, $3.3 \%$ says that the method depends on totaling a percentage from the item direct cost, and $14.8 \%$ says that the method is vary from one project to another.

Table 5. The method used to determine the field overheads costs.

\begin{tabular}{|c|c|c|}
\hline Percent (\%) & Frequency & Method \\
\hline 70.5 & 43 & $\begin{array}{l}\text { Detailed calculation based on the } \\
\text { contractual condition }\end{array}$ \\
\hline 8.2 & 5 & Percentage of the total tender cost \\
\hline 3.3 & 2 & $\begin{array}{l}\text { A lump sum added to the value of the } \\
\text { tender }\end{array}$ \\
\hline 3.3 & 2 & Percentage of the item direct cost \\
\hline 14.8 & 9 & Vary from one project to another \\
\hline 100.0 & 61 & Total \\
\hline
\end{tabular}

The result shown above reveals that the majority of companies follow the detailed calculation based on the contractual condition; this result may be attributed to the diversity in contracts from one project to another. In Gaza Strip, you may find specific requirements vary from owner to another or from project to project. Hence, no specific amount or percentage could be applicable. Almost the same results cope with [1] whereas $71 \%$ of the survey respondents' estimate based on detailed calculation upon the contractual condition. Another survey in the USA by[25] revealed that $83 \%$ of responding contractors estimated field overheads in a detailed manner. In Hong Kong, 94\% of the respondents estimate in details reference to the contract condition as stated by [10]. It seems that most of contractors spent their efforts and time in calculating the field overheads cost.

\subsection{Method Used to Determine the HOOH Costs}

Table 6 shows that $44.3 \%$ says that the method followed to determine the home office overheads costs depends mainly 
on detailed calculation which is based on the records and experience. While $23.0 \%$ says that the method depends on adding a percentage of the total tender cost. 3.3\% says that the method depends on totaling a percentage of the item direct cost, and $29.5 \%$ says that the method is vary from one project to another.

Table 6. The method followed to determine the $\mathrm{HOOH}$ costs.

\begin{tabular}{lll}
\hline Percent (\%) & Frequency & Method \\
\hline 44.3 & 27 & $\begin{array}{l}\text { Detailed calculation based on the records } \\
\text { and experience }\end{array}$ \\
23.0 & 14 & Percentage of the total tender cost \\
0.0 & 0 & Percentage of the labors costs in the project \\
3.3 & 2 & Percentage of the item direct cost \\
29.5 & 18 & Vary from one project to another \\
100.0 & 61 & Total \\
\hline
\end{tabular}

One of the main results has shown the importance of experience in deciding the value of $\mathrm{HOOH}$ in tender pricing. It is not static value or percentage but it is varying from project to project $(29 \%)$, depending on the estimator experience. Furthermore, instability of political situation in Gaza Strip has created no clear trend. So, the apparent problem lies in the uncertainty in the volume of work that the company can successfully being awarded to decide the exact proportion.

\subsection{The Distribution of Overheads Costs on Items}

Table 7 shows that $73.8 \%$ says that overheads costs is equally distributed within each item proportionally to the total contract value. While, $8.2 \%$ says that overheads costs is distributed by loading on specific items. $1.6 \%$ says that overheads costs distributed in front loading method. $1.6 \%$ says that overheads costs distributed in back loading method, and $14.8 \%$ says that there is no specific method for the distribution of overheads costs.

Table 7. Distribution of overheads costs on the items.

\begin{tabular}{|c|c|c|}
\hline Percent (\%) & Frequency & The distribution of overheads costs \\
\hline 73.8 & 45 & $\begin{array}{l}\text { Equally distributed within each item } \\
\text { Proportionally to the total contract }\end{array}$ \\
\hline 8.2 & 5 & Loading on specific items \\
\hline 1.6 & 1 & Front loading \\
\hline 1.6 & 1 & Back loading \\
\hline 14.8 & 9 & No specified method \\
\hline 100.0 & 61 & Total \\
\hline
\end{tabular}

It is a good behavior that the majority of companies follow the distribution of overhead cost on the items in proportion to the total contract. That behavior reflected positively on solving claims of suspension, delay by the owners, and termination. Hence, it helps in minimizing disputes with the owners in determining contractor financial damages.

\subsection{Identifying the Factors That Affect the Overheads Costs}

\subsubsection{Factors Attributed to the Managerial Capacity and Policies}

Table 8 shows the factors that affect on the overhead costs that attributed to the managerial capacity of the company and its policies in general. The factors are ranked according to RII:

1. The first factor was the expertise in the determination of the overheads costs percentage during the pricing of tenders with RII equal "0.93". It is concluded that the experience is very important in the process of estimating overhead costs because of its sensitivity and a decisive role in winning the tender.

2. The second factor was the company's ability to adhere to the implementation of projects according to the specification within the contractual period, whereas the RII equal "0.93". The company's ability to complete the project to the required specifications will help to reduce miss-technical works that may need remediation. Hence, delaying the project and increase overhead costs required to follow-up to mean while delay.

3. The third factor was the company's ability to cope with the problems during the implementation, whereas the RII equal" $0.90 "$. In fact, the company's ability to address problems during the implementation period will therefore reduces the size of the required overhead expenses that may enter the contractor in losses.

4. The fourth factor was doing financial auditing for expenses and revenues in periodic and continuous manner, whereas the RII equal"0.87". Periodic financial auditing will but the contractor in view of his financial status. In addition, it will enhance the records which will be benefit in coming project.

5. The fifth factor was the company's ability to identify and expect risks, whereas the RII equal " 0.86 ". The ability of contracting company in identifying the risk will guide the estimator in estimating of overheads accurately upon the degree of this risk.

Table 8. Factors related to the managerial capacity and policies.

\begin{tabular}{|c|c|c|c|c|c|c|}
\hline Rank & p-value & T test & Relative index(\%) & Std. Deviation & Mean & Influencing Factor \\
\hline 1 & 0.0 & 25.74 & 0.93 & 0.50 & 4.67 & $\begin{array}{l}\text { Expertise in the determination of the overheads costs percentage } \\
\text { during the pricing of tenders }\end{array}$ \\
\hline 1 & 0.0 & 27.59 & 0.93 & 0.47 & 4.67 & $\begin{array}{l}\text { The company's ability to adhere to the implementation of projects } \\
\text { according to the specification within the contractual period }\end{array}$ \\
\hline 3 & 0.0 & 19.58 & 0.90 & 0.59 & 4.49 & $\begin{array}{l}\text { Company's ability to cope with the problems during the } \\
\text { implementation }\end{array}$ \\
\hline 4 & 0.0 & 12.58 & 0.87 & 0.83 & 4.34 & $\begin{array}{l}\text { Doing financial auditing for expenses and revenues in periodic and } \\
\text { continuous manner }\end{array}$ \\
\hline 5 & 0.0 & 14.55 & 0.86 & 0.68 & 4.28 & The company's ability to identify and expect risks \\
\hline 6 & 0.0 & 11.31 & 0.83 & 0.79 & 4.15 & Company response in finding solutions for claims and disputes \\
\hline
\end{tabular}




\subsubsection{Factors Related to the Work Environment and Project Circumstances}

Table 9 shows the opinion of the respondents about the factors that affect on the overheads cost that related to the work environment and project circumstances. The first factor was "Closure and the inability to obtain materials", whereas the RII equal "0.94". It is normal to get closure on the rank number one, where the closure means delays in obtaining raw materials. Thus, increasing the duration of the project which would result in increased overhead costs, and putting the contractor in losses.

1. The second factor was "Financial liquidity of the company" with relative index "0.93". Financial liquidity will help the company to commit itself to the project duration. Hence, avoid delays. The desired goal come through the supplying of raw materials in a timely manner with more cheaper prices, bring the project within the required specifications, and provide an excellent crew to work, will thereby reduce the overhead costs to a minimum.

2. The third factor was "Mechanism of contractor financial dues (payments)" with relative index "0.91". Payments mechanism to the contractor will control the financial liquidity of the project is significant. Thus, how the contractor will manage the implementation of the project. As explained above, liquidity is clearly affecting the overhead costs. The contractor can determine the overheads expenses at the time of pricing depending on the payments policy, which will be followed by the client, for example, is there a an advance payment, the amount of the advance payment, and time for paying after submission the request.

3. The forth factor was "owner's commitment toward payments as scheduled" with relative index "0.90". The commitment toward payments schedule is differ from client to client. Sometimes you find delay in the payments disbursement to the contractor in contrast with periods specified by the contract, which negatively affects the project's progress. Hence, delay of the project schedule, and automatically becoming more and more overheads expenses than expected

4. The fifth factor was "The Company's experience in implementing similar projects" with relative index 0.88 ". The company's experience in implementing similar projects provide an opportunity for the contractor to determine accurately the amount of overheads expenses of the project planned to be priced .

Table 9. Factors related to the work environment and project circumstances.

\begin{tabular}{lllllll}
\hline Rank & p-value & T test & Relative index(\%) & Std. Deviation & Mean & Influencing factor \\
\hline 1 & 0.00 & 25.82 & 0.94 & 0.52 & 4.72 & Closure and the inability to obtain materials \\
2 & 0.00 & 22.14 & 0.93 & 0.57 & 4.64 & Financial liquidity of the company \\
3 & 0.00 & 19.07 & 0.91 & 0.64 & 4.57 & Mechanism of contractor financial dues (payments) \\
4 & 0.00 & 16.14 & 0.90 & 0.72 & 4.49 & Owner's commitment toward payments as scheduled \\
5 & 0.00 & 17.14 & 0.88 & 0.64 & 4.41 & The company's experience in implementing similar projects \\
\hline
\end{tabular}

Critical value of $\mathrm{t}$ at $\mathrm{df} " 60 "$ and significance level 0.05 equal 2

\section{Conclusion}

Majority of contractors in Gaza Strip are aware towards overheads concept and they have good knowledge about the components of overheads. Accordingly, companies' owners or senior mangers are usually estimate overheads costs during the pricing of tenders.

Around one third of contracting companies in Gaza Strip do not depend on historical data during pricing process.

The $\mathrm{OH}$ cost is calculated based on detailed calculation for all items required by contractual conditions. No specific amount or percentage could be applicable to be added. Furthermore, during the bidding stage the overheads costs is equally distributed within each item proportionally to the total contract value.

High competition in Gaza construction industry may enforce the contractors to reduce the $\mathrm{HOOH}$ percentage. Most of contractors believe that submission of overhead breakdown within their bids will give them opportunity to review the overheads accurately before submission.

The first five factors attributed to the managerial capacity and company's policies that affect the estimation of overheads were the experience in the determination of the overheads costs percentage during the pricing of tenders, the ability to adhere to the specification within the contractual period, the ability to cope with the problems during the implementation, doing financial auditing for expenses and revenues in periodic and continuous manner, and the ability to identify and expect risks.

The first five factors attributed to the work environment and project circumstances that affect the estimation of overheads through the pricing process were the repetitive closure of boarders and the inability to obtain materials through trading terminals, financial liquidity of the company, mechanism of contract payments, owner's commitment toward payments, the experience in implementing similar projects.

\section{References}

[1] Assaf, S. A., Bubshait, A. A., Atiyah, S. and Al-Shehri, M. (2001), "The management of construction company overhead costs", International Journal of Project Management, Vol.19, pp. 295-303. 
[2] Dagostino, F. R. (2002), "Estimating in building construction", 6th edition, Prentice-Hall, Englewood Cliffs, N.J.

[3] Abdul-Malak, M. A. U., El-Saadi, M. M. H. and Abou-Zeid, M. G. (2002), "Process model for administrating construction claims", Journal of Management in Engineering, ASCE, Vol.18 No.2, pp. 84-94.

[4] Zack, Jr. James G. (2002), "Calculation and recovery of home office overhead", Construction management Journal, International Cost Engineering Council, 3rd world Congress on cost Engineering, Project Management and Quantity Surveying, 6th Pacific Association of Quantity Surveyors congress, Melbourne, Australia, April 14-18.

[5] McKibbin, R. and Stokes, M. (2005), "Preparation and presentation of claims for delay", Precept Programme Management Limited, Stanford House, London.

[6] Holland, N. and Hobson, D. (1999), "Indirect cost categorization and allocation by construction contractors", Journal of Architectural Engineering, ASCE, Vol.5 No.2, pp. 49-56.

[7] Cilensek R. (1991), "Understanding contractor overhead", Cost Engineering, AACE, Vol.33 No. 12.

[8] Coombs, W. E., and Palmer, W. J. (1995), "Construction accounting and financial management", 5th edition, McGrawHill, New York.

[9] Peurifoy, R. L., and Oberlender, G. D. (2002), "Estimating construction costs", 5th edition, McGraw-Hill, New York.

[10] Chan,C. T. W. and Pasquire, C. (2002), "Estimation of project overheads: a contractor perspective", in Greenwood, D. (Ed.), 18th Annual ARCOM Conference, 2-4 September 2002, and University of Nothumbria, Vol. 1 Association of Researchers in Construction Management, pp. 53-62.

[11] Lowe, S., Bielek, R. and Burnham, R. (2003), "Compensation for contractors' home office overhead: A Synthesis of highway practice", American Association of State Highway and Transportation Officials, National Cooperative Highway Research Program, National Research Council (U.S.), Los Angeles, California

[12] Ruf, H. B. and Ruf S. (2007), "Documentation and presenting cost in underground construction claims", No-Dig Conference \& Exhibition, San Diego, California April 16-19, 2007

[13] Neil, J. M. (1981), “Construction cost estimating for project control”, Prentice-Hall, Englewood Cliffs, N.J.
[14] Shelton, F. and Brugh, M. (2002), "Indirect costs of contracts", Journal of Construction Accounting and Taxation, Vol. 12 No. 4, pp. 3-9.

[15] Clough, R., Sears, G. and Sears, K. (2000), "Construction project management", 4th edition, John Wiley \& Sons, New York.

[16] Irwin II, W. (2005), "Current Issues to watch for in construction claims, part III: Overhead Claims",http://www.lorman.com/newsletters/article.php?articl e_id $=81 \&$ newsletter_id $=22 \&$ category_id $=3 \&$ topic $=\mathrm{CN}$, (accessed March 2012).

[17] Stewart, R. D., Wyskida, R. M., Johannes, J. D. (1995), "Construction cost estimating. In: cost estimator's reference manual", 2nd edition. John Wiley \& Sons, Inc.

[18] Boussabaine, A.H. and Elhag, T. (2001), "Tender price estimation using artificial neural networks", Journal of Financial Management Property Construction, Vol. 63 No.3, pp.193-208.

[19] Hegazy T. and Ayed, A., (1998) "A Neural Network Model for Parametric Cost Estimation of Highway Projects," Jr. of Construction Engineering \& Management, ASCE, 24(3), 210218.

[20] Mason, A.K. and Kahn, D.J. (1997), "Estimating costs with fuzzy logic", Proceedings of the 1997 41st Annual Meeting of AACE International, July 13-16, Dallas, TX, 6 pages.

[21] Sha'ath, K. and Singh, G. (1993), "A Stochastic cost engineering system (SCENS) applied to estimating and tendering for bill of quantities contracts", In: Proceedings of 5th International Conference on Computing in Civil and Building Engineering, California, USA, 7-9 June, pp.70-77.

[22] Elhag, T. and Boussabaine, A.H. (1998), "Factors affecting cost and duration of construction projects", In: EPSRC Research Report, Phase (1)

[23] Eksteen, B. and Rosenberg, D. (2002), “ The management of overhead costs in construction companies" in Greenwood, D. (Ed.), 18th Annual ARCOM Conference, 2-4 September 2002, and University of Nothumbria, Vol. 1 Association of Researchers in Construction Management, pp. 13-22.

[24] ElSawy, I., Hosny, H. and Abdel Razek, M. (2011), “A Neural Network Model for Construction Projects Site Overhead Cost Estimating in Egypt". IJCSI International Journal of Computer Science Issues, Vol. 8 No. 1, pp. 273-283.

[25] Hegazy, T. and Moselhi, O. (1995), "Elements of cost estimation: a Survey in Canada and the United States", Cost Engineering, Vol.37 No.5, pp.27-33. 